\title{
Production of Bio-Calcium Oxide Derived from Hatchery Eggshell Waste Using an Industrial-Scale Car Bottom Furnace
}

\author{
Ajchara Imkum Putkham ${ }^{1}$, Suwanan Chuakham ${ }^{2}$, Yuwadee Chaiyachet ${ }^{2}$, Tanapon Suwansopa ${ }^{2}$ and \\ Apipong Putkham ${ }^{2, *}$
}

${ }^{1}$ Department of Chemistry, Faculty of Science, Naresuan University, Phitsanulok, 65000, Thailand

${ }^{2}$ Sustainable Environment and Energy Research Unit, Mahasarakham University, Mahasarakham, 44150, Thailand

*Corresponding Author: Apipong Putkham. Email: apipong.p@msu.ac.th

Received: 03 August 2021 Accepted: 01 October 2021

\begin{abstract}
The valorization of eggshell waste as bio-calcium oxide is crucial for pollution prevention and supporting sustainable development. There are several reports on the thermal conversion of eggshell waste to calcium oxide for the partial or complete substitution of natural lime applications. However, this paper reports the thermal decomposition of large amounts of hatchery eggshell waste on an industrial-scale car bottom furnace for the first time. The hatchery eggshell waste was sundried and placed into five stacked trays in the car bottom furnace. The calcination of the eggshell waste was conducted at $900^{\circ} \mathrm{C}$ for 3 and $4 \mathrm{~h}$ under an atmosphere of air. Both the physical and chemical properties of the eggshell samples and the bio-quicklime products were carefully examined by TGA, SEM, XRD, FTIR, and XRF. The results demonstrate that the purity of calcium oxide in the quicklime products increased from $79 \%$ to $87 \%$ upon increasing the calcination time from 3 to $4 \mathrm{~h}$. However, the color of the calcined eggshell samples at the surface of the pile was white while the color of the product beneath the surface was black or dark gray. The purity of the calcium oxide of both the black and white calcined samples was $76.4 \%$ and $91.5 \%$, respectively. These results indicate the limited efficacy of the car bottom furnace for thermal decomposition of the large amount of eggshell waste to calcium oxide. Additionally, the production cost of bio-calcium oxide is approximately twice the cost of industrial grade lime. For further industrial applications, the furnace should contain the mixing equipment for improving the thermal decomposition of the large pile of eggshell waste. Furthermore, the oil burner system may be used in order to reduce fuel costs.
\end{abstract}

\section{KEYWORDS}

Eggshell; Calcium oxide; waste management; thermal decomposition; catalyst; quicklime

\section{Introduction}

The global consumption of eggs and chicken meat has dramatically increased in the past few years, since both are a great dietary source for humans. In 2020 alone, the amount of eggshells produced in the leading egg-producing countries was estimated to be 936 billion $\mathrm{kg}$ [1]. In addition, the production of eggs and chicken meat both generate several waste materials, including wastewater and solid hatchery waste. Solid hatchery waste comprises empty eggshells, dead embryos, dead chicken, and viscous liquid from decaying tissue and eggs [2]. In Thailand, the amount of hatchery eggshell waste generated annually is 
about 876,000 tons and most of this waste is usually discarded in landfills, requiring high management costs [3]. This large amount of waste leads to several environmental impacts, e.g., odor nuisance, ground water pollution, and social conflict. Valorization or recycling of the eggshell waste as a secondary raw material could possibly reduce these environmental problems and the cost of production, and also help support the sustainable production of the chicken industry [4].

Eggshells are bio-ceramic materials composed of 94\%-97\% calcium carbonate, with the remaining 3\%$6 \%$ being protein and trace inorganic materials. From the inside outwards, the eggshell structure normally consists of a mammillary layer, a palisade layer, a vertical layer, and a cuticle layer. The mammillary layer is mainly composed of calcite crystals and a small amount of organic matter [5,6]. Eggshells have a high potential for being used as a cheap alternative calcium source in food supplements and medical applications [7,8]. Calcium carbonate eggshells also have the potential to act as fillers in various industrial products, e.g., cement, plastic, paper, glass, and ceramics. Recently, many researchers focused their attention on converting eggshells to calcium oxide or quicklime for various applications, e.g., catalysis in biodiesel production, bioquicklime for building, carbon dioxide storage, and environmental remediation [9-11]. There are several notable applications of calcium oxide derived from eggshells, as follows. Nath et al. pointed out that composite cement with a partial replacement of cement with $5 \%, 10 \%$, and $15 \%$ by weight of calcium oxide derived from eggshells exhibited antibacterial properties, which may help to preserve building surfaces [12]. Biogas production from the anaerobic digestion of the palm oil mill effluent increased by 1.5 times when nano-calcium oxide catalyst prepared from eggshells was included [13]. Additionally, the hydroxyapatite nanostructure obtained from eggshell powder is a potential source of dental pulp stem cells and bone tissue engineering applications [14,15]. Interestingly, Minakshi et al. reported that the calcium oxide obtained from eggshells can possibly be used as a cathode/anode material in batteries and capacitors [16].

Normally, chicken eggshells can be converted into calcium oxide via a thermal decomposition process at temperatures higher than $780^{\circ} \mathrm{C}[17,18]$. It should be noted that numerous researchers have conducted studies on the effects of various calcination conditions for synthesizing calcium oxide, e.g., the heating rate, the calcination temperature, and the calcination time [19-21]. Pornchai et al. proposed that the optimum

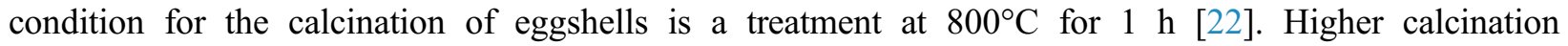
temperatures and prolonged calcination times decrease the surface area, pore size, and reactivities of the calcium oxide product [23-26]. However, research involving eggshell calcination has normally been conducted in lab-scale furnace with a small amount $(0.5-10 \mathrm{~g})$ of eggshells being used for each batch. To the best of our knowledge, no studies involving the calcination of eggshells in an industrial-scale furnace have been reported before. The heating process of the furnace plays a significant role, since major rearrangements of the raw material microstructure occur which have a direct impact on the properties of the final product [24]. Thus, up-scaling to an industrial scale is crucial for assessing the optimum operating conditions, as it is similar to a commercial scale. A conventional car bottom furnace is widely used in various industrial processes and is normally designed for the handling of batches and for multiple configurations of loads. In addition, car bottom furnaces have several advantages, such as a slightly lower capital cost, a long lifespan, and simple operating and maintenance techniques [27]. Consequently, the main objective of this work is to investigate the properties of bio-calcium oxide derived from eggshell hatchery waste via thermal decomposition methods in the industrial-scale car bottom furnace. A calcination temperature of $900^{\circ} \mathrm{C}$ with different residence times is used in this work. In addition, the fuel consumption cost of the bio-calcium oxide product is determined.

\section{Materials and Methods}

\subsection{Materials}

Solid hatchery waste collected from a large broiler hatchery farm located in the northeast of Thailand was used. On a daily basis, this farm produces approximately 1.0-1.5 tons of solid hatchery waste. 
Firstly, dead embryos from the solid hatchery waste were manually separated, while the remaining solid hatchery waste, which consisted of the shell plus the membrane and viscous liquid, was sundried for three days. Gravimetric analysis showed that the moisture content in the solid and sundried hatchery waste was $24.7 \pm 0.3 \mathrm{wt} \%$ and $2.5 \pm 0.1 \mathrm{wt} \%$, respectively. As shown in Fig. 1A, the dried solid hatchery waste was then manually shredded into flake-shaped particles by a 3-hp shredder machine (NiMUTECM-2). Following this, the median particle size (D50) of the shredded hatchery waste was determined by sieve analysis and was found to be $6.3 \mathrm{~mm}$. This shredded hatchery waste was kept for the calcination experiment. Milled industrial calcium oxide, produced from the calcination of natural limestone at $900^{\circ} \mathrm{C}$ for $18 \mathrm{~h}$, was obtained from a local lime industry.

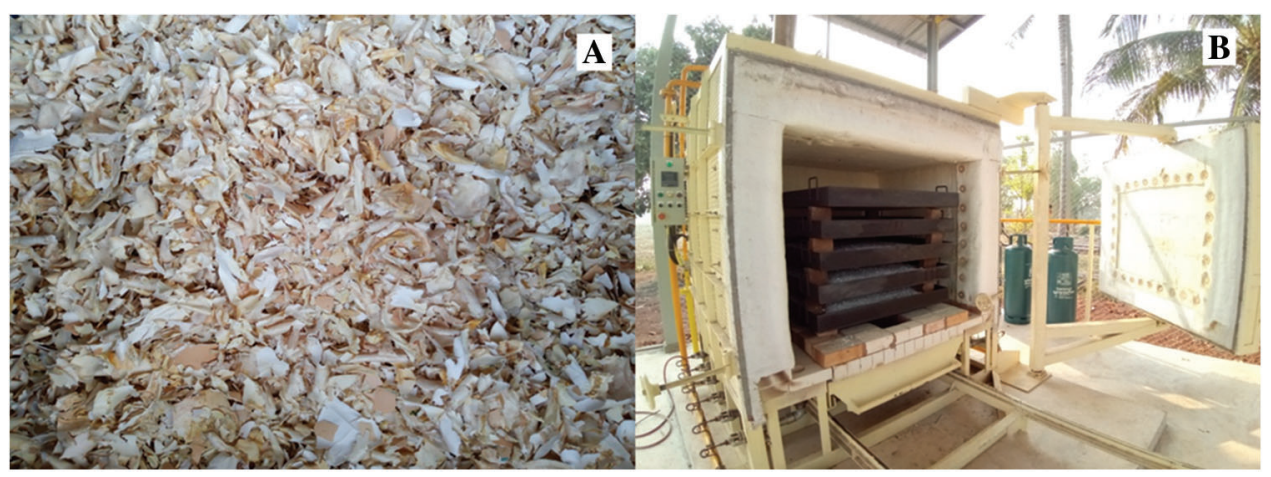

Figure 1: Digital images of the dried solid hatchery waste (A) and the industrial car bottom furnace with five stacked trays (B)

\subsection{Production of Bio-Quicklime}

The industrial-scale car bottom furnace used in this work was made from heat resistant bricks lined with ceramic fiber and welded with stainless steel shelves, as shown in Fig. 1B. The volume of the effective heating zone inside the furnace was approximately $1.44 \mathrm{~m}^{3}$. Both the left- and right-hand sides of the bottom of the furnace were equipped with six venturi gas burners to provide a uniform temperature distribution in the furnace chamber. Liquid petroleum gas (LPG) was used as the fuel for heating the furnace and a type-K thermocouple was installed for monitoring the furnace temperature. The shredded hatchery samples were placed in five stacked stainless-steel trays with dimensions of $100 \mathrm{~cm} \times 100 \mathrm{~cm} \times$ $10 \mathrm{~cm}$. Each tray contained $50 \mathrm{~kg}$ of the shredded hatchery sample, amounting to a total sample weight of $250 \mathrm{~kg}$. As previously mentioned, eggshells normally decompose above $780^{\circ} \mathrm{C}$. Thus, the batch calcinations of the shredded hatchery waste were carried in this study out under an atmosphere of air at $900^{\circ} \mathrm{C}$, which is similar to the calcination temperature of industrial calcium oxide. However, these batch calcination experiments were holding at $900^{\circ} \mathrm{C}$ for $3 \mathrm{~h}$ and $4 \mathrm{~h}$ with a heating rate of approximately $30^{\circ} \mathrm{C} / \mathrm{min}$ due to limitations of the small gas burners within the furnace. The fuel consumption rate of each calcination batch was recorded to determine the operating cost.

\subsection{Product Characterization}

The thermal decomposition behavior of the solid hatchery waste was determined by thermogravimetric analysis (TGA; TA Instruments SDTQ600). Initially, samples with weights of 2-3 g were heated in a ceramic crucible at $5^{\circ} \mathrm{C} / \mathrm{min}$ from room temperature to $1000^{\circ} \mathrm{C}$ in an inert $\mathrm{N}_{2}$ atmosphere. Both the physical and chemical characteristics of the calcined products were systematically determined by the following instruments. Color measurements were determined using a Konica Minolta Chroma Meter (CR-400) based on the CIELAB coloring system [28]. The color data obtained were in the form of $\mathrm{L}^{*}$, $\mathrm{a}^{*}$, and $\mathrm{b}^{*}$ values. The value $\mathrm{L}^{*}$ indicates the light, $\mathrm{a}^{*}$ shows the green/red coordinates, and $\mathrm{b}^{*}$ shows the yellow/ 
blue coordinates. The crystalline structures of the samples were examined by X-ray powder diffraction (XRD; Bruker D8 Advance) using $\mathrm{Cu}-\mathrm{K} \alpha$ radiation at $40 \mathrm{kV}$ over a $2 \Theta$ range from $20^{\circ}$ to $80^{\circ}$ with a step size of $0.04^{\circ}$ at a scanning speed of $3 \% \mathrm{~min}$. The obtained XRD diffractograms were compared with the JCPDS (Joint Committee on Powder Diffraction Standards) data. The presence of functional groups in the samples was determined by Fourier transform infrared spectroscopy (FT-IR) using a Perkin Elmer Frontier spectrometer. The surface microstructure and elemental composition of the samples were observed by scanning electron microscopy (SEM) using a Hitachi TM 4000 Plus microscope. Prior to undertaking SEM imaging, the samples were mounted on aluminum foil and sputter coated twice with gold. Loss on ignition (LOI) was performed at $1000^{\circ} \mathrm{C}$ and determined by a gravitational method. X-ray fluorescence (XRF; Bruker S4 Explorer) was used to quantitatively analyze the major minerals within the samples. The mean crystallite size was calculated using the Scherrer equation [25,29], as follows:

$d=\frac{K \lambda}{\cos \theta}$

where $d$ is the crystallite size, $K$ is the shape factor $(K=0.9), \lambda$ is the wavelength of the $\mathrm{X}$-rays $(\lambda=1.5406 \AA$ for $\mathrm{Cu} \mathrm{K \alpha}$ radiation), $\beta$ is the full width at half maximum in radians, and $\theta$ is the Bragg angle.

\section{Results and Discussion}

\subsection{Thermal Decomposition of the Solid Hatchery Waste}

The thermal behaviors of the eggshell membrane, the eggshell plus the internal membrane, and the eggshell were analyzed using TGA. For the eggshell membrane, the results show the presence of two main thermal events, as shown in Fig. 2. The first stage, with approximately $11 \%$ of total mass loss, is observed at $100^{\circ} \mathrm{C}$ and is attributed to the removal of physically adsorbed water on the membrane. The second stage, with approximately $8 \%$ of total mass loss, is initially observed from $200^{\circ} \mathrm{C}$ to $625^{\circ} \mathrm{C}$ and is related to the decomposition of organic matter. This result indicates that the eggshell membrane is possibly completely transformed to the volatile gas phase in this temperature range. The TGA curve obtained for the eggshell alone shows thermal stability up to $630^{\circ} \mathrm{C}$, where the total mass loss of approximately $4.5 \%$ is ascribed to both the trace organic material present in the shell and the organic waste adhered to the shell. A distinct thermal decomposition process occurring in the range of $630^{\circ} \mathrm{C}$ to $820^{\circ} \mathrm{C}$ with a mass loss of $43 \%$ corresponds to the decomposition of calcium carbonate into carbon dioxide and calcium oxide residue. As expected, the TGA curve of the eggshell plus membrane exhibits the combined thermal behaviors of both the eggshell and its membrane. This TGA curve presents three main events of mass losses. The first loss $(\sim 4.6 \%)$ occurs at $50-200^{\circ} \mathrm{C}$ and is attributed to the loss of moisture content and some volatile organic matter in the eggshell and its membrane. Further calcination of the sample between $200^{\circ} \mathrm{C}$ and $590^{\circ} \mathrm{C}$ gave the second mass loss of $\sim 24.9 \%$ of the total sample mass. This second mass loss presents the volatilization of organic matter in the eggshell membrane. The third mass loss of $\sim 31.5 \%$, which occurred between $590^{\circ} \mathrm{C}$ and $825^{\circ} \mathrm{C}$, is responsible for the decomposition of calcium carbonate. In comparison, Lubis et al. [30] reported that the thermal decomposition temperature of natural limestone varies in the range between $640^{\circ} \mathrm{C}$ and $870^{\circ} \mathrm{C}$, which is broader than the range of the decomposition temperature of the eggshell waste observed herein. The reason is that natural limestone contains a variety of mineral contaminants, which result in different ranges of thermal decomposition.

In summary, the TGA data of the eggshell obtained from the solid hatchery waste is similar to previously published research. Cree et al. [20] observed the first mass loss of the eggshell powder of $5 \%$ up to $700^{\circ} \mathrm{C}$ and the main mass loss $(44 \%)$ occurred from $700^{\circ} \mathrm{C}$ to $900^{\circ} \mathrm{C}$. Tsuboi et al. [17] provided a very detailed description of the eggshell decomposition process, whereby the first mass loss begins with water vaporization, followed by the pore and crack formation, and then thermal degradation of the organic matter inside the outer shell membrane. Furthermore, the second mass loss of $43.23 \%$ corresponds to the 
thermal decomposition of the calcite in the eggshell. Additionally, the mass loss due to the decomposition of calcium carbonate found in this study is comparable to the mass loss of $43.8 \%$ of the decomposition of the chemical reagent grade calcium carbonate and the theoretical mass loss of $44 \%$ calculated from the calcium carbonate decomposition reaction [31,32]. From this study, we can conclude that the calcination of the eggshell alone and the eggshell plus the membrane obtained from the solid hatchery waste at $800^{\circ} \mathrm{C}$ yielded the calcium oxide product in $\sim 53.5 \%$ and $\sim 39 \%$, respectively.

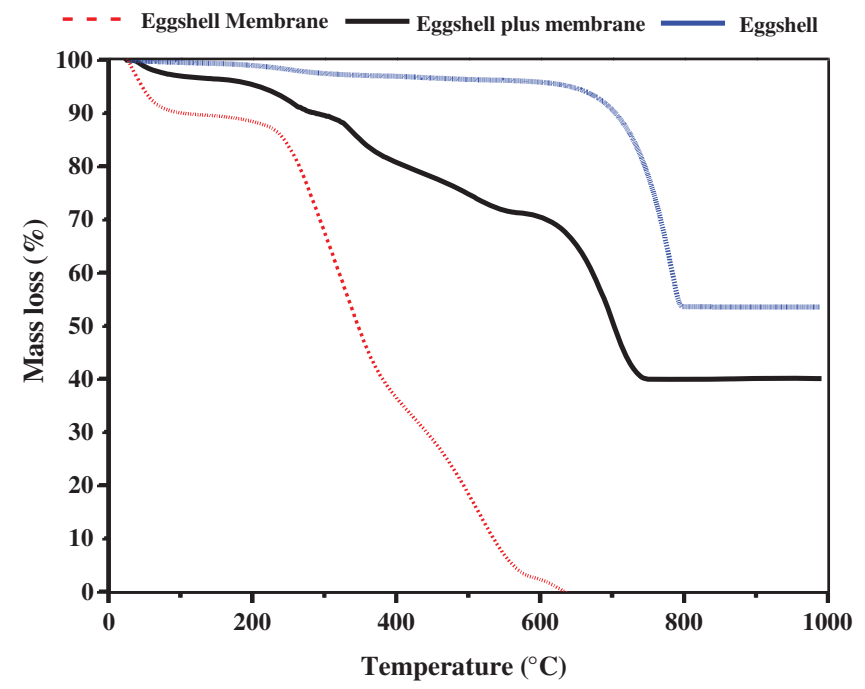

Figure 2: TGA curves of the eggshell membrane, the eggshell plus the internal membrane, and the eggshell derived from hatchery solid waste

\subsection{Morphology of the Calcined Product}

Figs. $3 \mathrm{~A}$ and $3 \mathrm{~B}$ show the bulk of the calcined hatchery eggshell waste after calcination of the sample at $900^{\circ} \mathrm{C}$ for $3 \mathrm{~h}$ and $4 \mathrm{~h}$, respectively. It is clear that there are no leftover eggshell membranes, since most of the eggshell membrane decomposes at temperatures higher than $625^{\circ} \mathrm{C}$, as found in the TGA results. The calculated bulk density of the hatchery eggshell waste in the tray was $549 \mathrm{~kg} \mathrm{~m}^{-3}$. In addition, the bulk density of the calcined eggshell heated at $900^{\circ} \mathrm{C}$ for $3 \mathrm{~h}$ and $4 \mathrm{~h}$ was 274 and $315 \mathrm{~kg} \mathrm{~m}^{-3}$, respectively. Furthermore, the color of the calcined eggshell samples at the surface of the pile was white, while the color of the product beneath the surface was black or dark gray. The bed thickness of the white and the black sample obtained by calcination of the eggshell at $900^{\circ} \mathrm{C}$ for $3 \mathrm{~h}$ was approximately $1.3 \mathrm{~cm}$ and $5.1 \mathrm{~cm}$, respectively. Additionally, the bed thickness of the white and the black sample obtained by calcination of the eggshell at $900^{\circ} \mathrm{C}$ for $4 \mathrm{~h}$ was approximately $1.8 \mathrm{~cm}$ and $4.3 \mathrm{~cm}$, respectively. As shown in Table 1, the results of the color parameters show that the raw eggshell has a slightly yellow-red color. The $\mathrm{L}^{*}$ values of the calcined eggshell are in the range from 57.83 to 96.20 . Based on these $\mathrm{L}^{*}$ values, black-3h has a darker color compared to the white-3h sample, and is similar to black-4h, which has a darker color than white-4h. The calcined eggshell samples tend to be white as the calcination time increases. According to the L* values, both the white-3h and white-4h samples also have a brighter color than industrial calcium oxide. The SEM images show the different surface morphologies of both the inner and outer surfaces of the hatchery eggshell waste and the black and white calcined eggshell waste. As shown in Fig. 4A, the outer surface of the eggshell exhibits a rough surface with small cracks throughout the cuticle layer of the eggshell. In contrast, several researchers reported that the outer surface of the eggshell appears to be relatively smooth and probably contains few small pores $[5,20]$. The rough surface and small cracks found on the outer surface of the eggshell in this study are possibly due to the grinding 
process utilized during sample preparation. For Fig. 4B, the cones of the mammillary layer are observed on the inner surface of the eggshell, which is similar to the observations of both Ketta et al. [5] and Hincke et al. [33]. After calcination of the sample at $900^{\circ} \mathrm{C}$ for $3 \mathrm{~h}$, some large cracks and large pores are observed on the outer and inner surfaces of the black calcined sample, as shown in Figs. 4C and 4D. These changes indicate that the calcium carbonate in the eggshell is partly thermally decomposed to carbon dioxide and calcium oxide. In comparison, a large number of macropores dominate the both the outer and inner surfaces of the white calcined sample. In this case, the cone shape of the mammillary layer has disappeared, which indicates further decomposition of calcium carbonate (Figs. 4E and 4F). However, some fibrous proteins are still found on the inner surface of the white calcined sample, which indicates an incomplete thermal decomposition of the eggshell to calcium oxide [17,20].

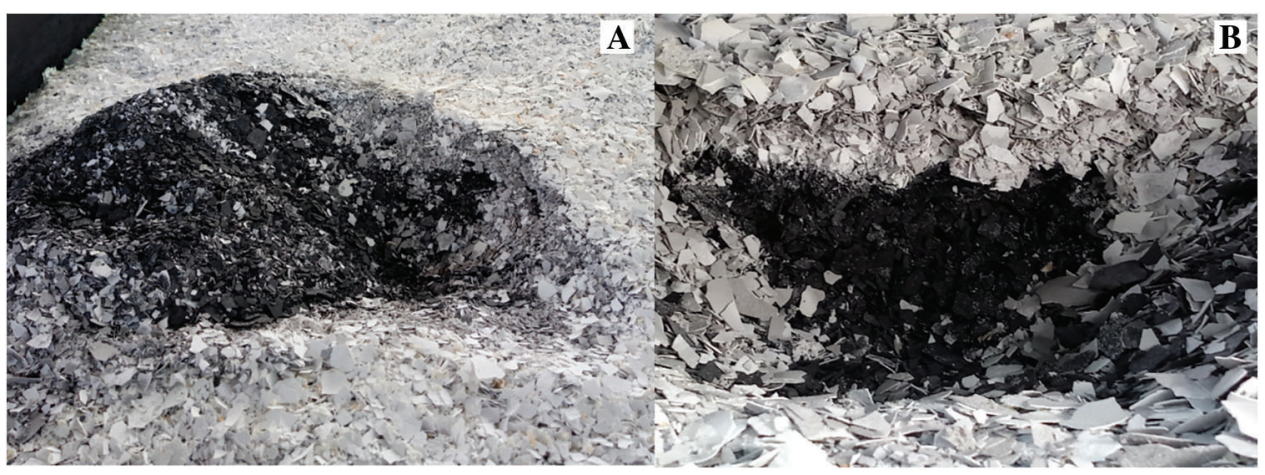

Figure 3: Digital images of the calcined solid hatchery waste prepared at $900^{\circ} \mathrm{C}$ for $3 \mathrm{~h}(\mathrm{~A})$ and $4 \mathrm{~h}(\mathrm{~B})$, with the white calcined sample covering the surface of the pile and the black calcined sample being present in the lower portions of the pile

Table 1: Values of $\mathrm{L}^{*}, \mathrm{a}^{*}$ and $\mathrm{b}^{*}$ for experimental samples

\begin{tabular}{llll}
\hline Sample & $\mathrm{L}^{*}$ & $\mathrm{a}^{*}$ & $\mathrm{~b}^{*}$ \\
\hline Black calcined sample-3h (black-3h) & 57.83 & 0.04 & 0.19 \\
Black calcined sample-4h (black-4h) & 61.32 & 0.12 & 0.32 \\
White calcined sample-3h (white-3h) & 95.13 & -0.01 & 1.78 \\
White calcined sample-4h (white-4h) & 96.20 & -0.01 & 1.74 \\
Industrial calcium oxide & 89.64 & -0.09 & 3.99 \\
Raw eggshell & 70.07 & 6.05 & 26.14 \\
\hline
\end{tabular}

Figs. 5A to 5D show typical SEM images of both the exterior and interior of the calcined eggshell heated at $900^{\circ} \mathrm{C}$ for $4 \mathrm{~h}$. The black calcined sample exhibits a very rough surface and long cracks on its outer surface, while the inner surface also exhibits large pores and extensive cracking throughout the mammillary layer (Figs. 5A and 5B). A distinguishable surface change from rough to grain-shaped was observed for both the outer and inner sides of the white calcined sample, as shown in Figs. 5C and 5D. The appearance of this grain-shaped surface after heat treatment of the eggshell is similar to previous reports which described the shape as the dumbbell-like or rod-like [34,35]. Additionally, macropores are extensively formed between the grain shapes. The change in the microstructure of this white calcined sample is possibly due to the decomposition of calcium carbonate to calcium oxide and carbon dioxide [36]. 


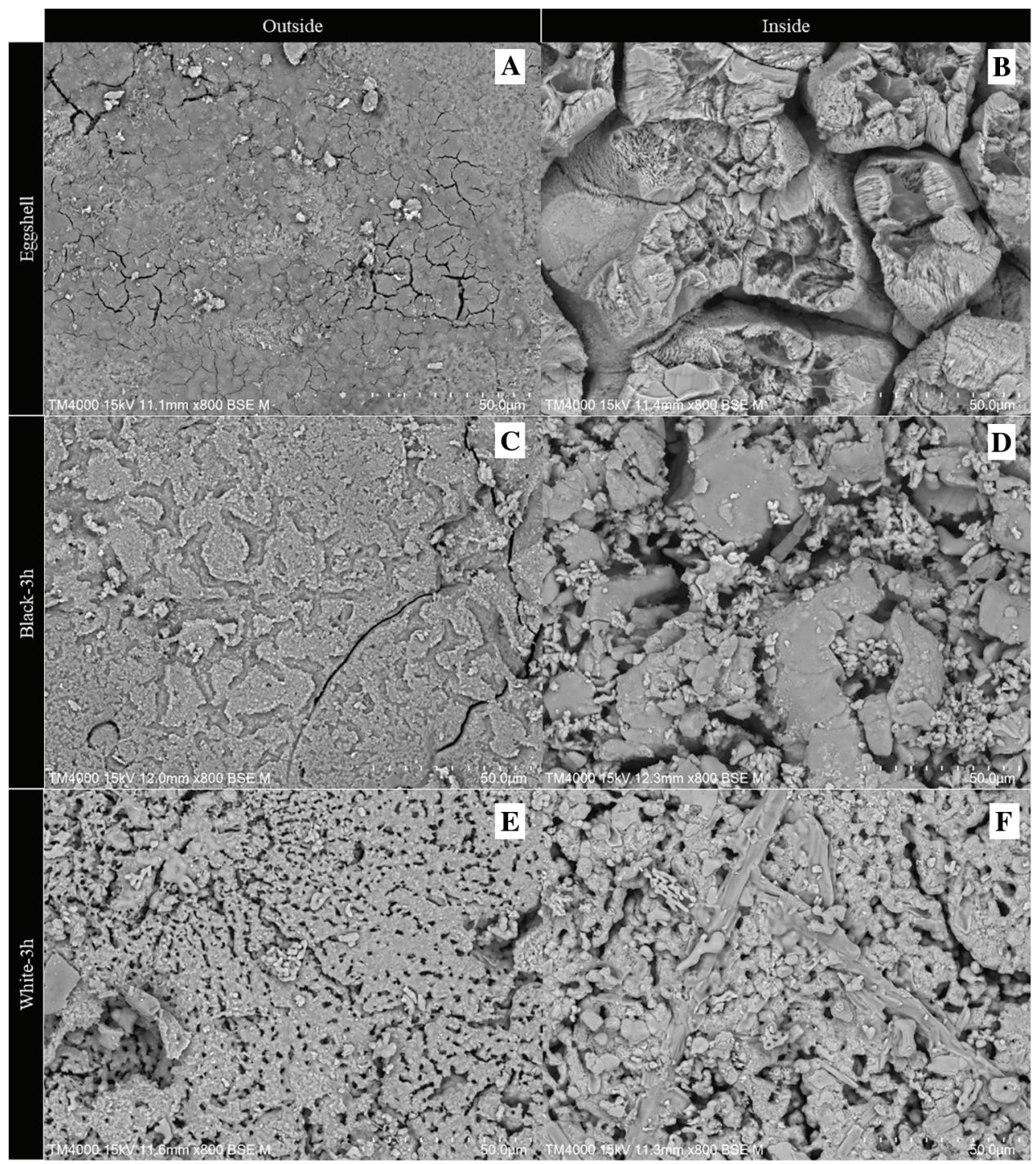

Figure 4: SEM images at $800 \times$ magnification of both the inner and outer surfaces of the hatchery eggshell waste (A, B), and the black (C, D) and white (E, F) samples calcined at $900^{\circ} \mathrm{C}$ for $3 \mathrm{~h}$, denoted as black-3h and white-3h, respectively

In comparison, both surface structures of the black calcined eggshells heated at $900^{\circ} \mathrm{C}$ for 3 and $4 \mathrm{~h}$ were similar. This result indicates that a longer calcination time has a limited effect on the decomposition of the eggshell beneath the large pile of the eggshell sample. In contrast, the surface of the white calcined sample increases because of the calcination time increases from 3 to $4 \mathrm{~h}$. These SEM results indicate that heating a large pile of eggshell sample in the five stacked stainless steel trays leads to incomplete thermal decomposition of calcium carbonate in the eggshell. This is possibly due to the stacking load and the deep layer of the sample, which causes both non-uniform heating and a reduced heat transfer to the deeper layers [37,38]. In this study, an incomplete thermal decomposition of the eggshell sample may further indicate that the six venturi gas burners installed at the bottom of the furnace are inadequate for providing a uniform temperature distribution in the furnace chamber. 


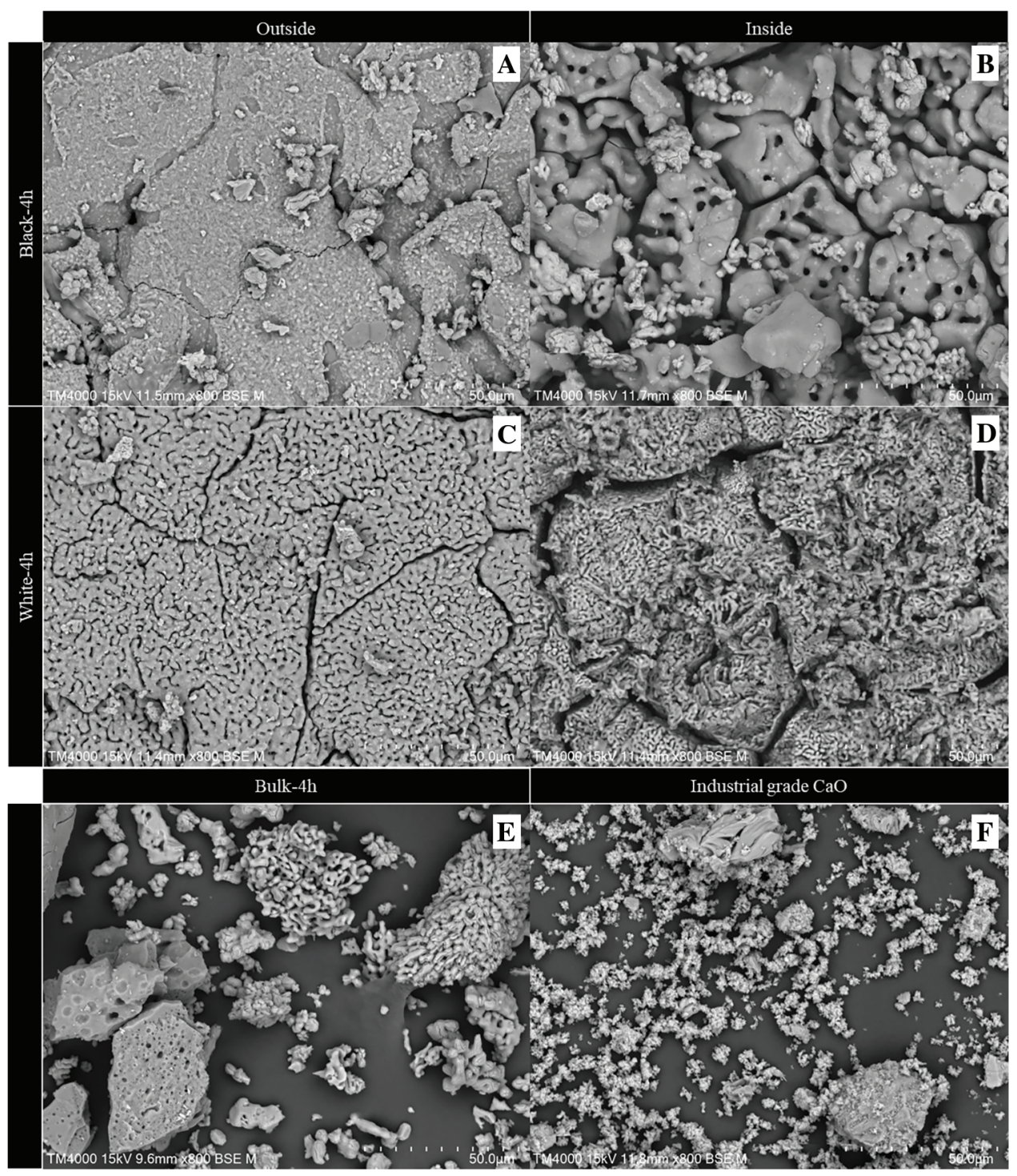

Figure 5: SEM images at $800 \times$ magnification of the black $(A, B)$ and white $(C, D)$ samples calcined at $900^{\circ} \mathrm{C}$ for $4 \mathrm{~h}$, denoted as black- $4 \mathrm{~h}$ and white- $4 \mathrm{~h}$, respectively, the bulk sample calcined at $900^{\circ} \mathrm{C}$ for $4 \mathrm{~h}$ (E), and industrial calcium oxide (F)

Fig. 5E shows the SEM image of the bulk calcined sample heated at $900^{\circ} \mathrm{C}$ for $4 \mathrm{~h}$. It exhibits both porous particles of the white sample and less porous particles of the black calcined sample. Additionally, Fig. 5F also shows the SEM image of industrial calcium oxide, which contains small grain-shaped particles of calcium oxide throughout, with some large rigid particles.

\subsection{Powder X-Ray Diffraction}

The peaks of the XRD patterns were identified by matching them with the data from the Joint Committee on Powder Diffraction Standards: JCPDS file No. 017-0912 and Card No. 47-1743 for calcium oxide and calcium carbonate, respectively $[18,39,40]$. The characteristic peaks of all XRD patterns obtained from this study were high in intensity and narrow in spectral width, indicating that the calcined products were of good crystallinity. Additionally, no crystal impurity was observed in the XRD pattern in the range of 
$10^{\circ}<2 \theta<80^{\circ}$. Fig. 6 shows the XRD patterns of the bulk bio-quicklime synthesized from hatchery eggshell waste at $900^{\circ} \mathrm{C}$ for 3 and $4 \mathrm{~h}$. The bulk samples were denoted as bulk-3h and bulk-4h, respectively. In both cases, diffraction peaks corresponding to $\mathrm{CaCO}_{3}$ and $\mathrm{CaO}$ were observed. The presence of $\mathrm{CaCO}_{3}$ is indicated by peaks with $2 \theta$ at $23.2^{\circ}, 29.3^{\circ}, 39.4^{\circ}, 43.7^{\circ}, 47.4^{\circ}$, and $48.4^{\circ}$, while less intense peaks of $\mathrm{CaO}$ are found at $2 \theta=32.2^{\circ}, 37.3^{\circ}, 53.8^{\circ}, 64.2^{\circ}$, and $67.5^{\circ}[19,41]$. These results indicate that, in both bulk calcined eggshell waste materials, calcium carbonate partly decomposed to calcium oxide. Furthermore, increasing the calcination time from 3 to $4 \mathrm{~h}$ has a small effect on the crystal structure of the eggshell pile sample, which is in line with the SEM findings. Similar patterns of strong intense peaks of $\mathrm{CaCO}_{3}$ are observed in the XRD patterns of the black samples separated from the eggshell waste calcined at $900^{\circ} \mathrm{C}$ for $4 \mathrm{~h}$, which are shown in Fig. 6. In contrast, five significant XRD peaks of $\mathrm{CaO}$ at $2 \theta=32.4^{\circ}, 37.5^{\circ}, 54.0^{\circ}, 64.5^{\circ}$, and $67.6^{\circ}$ can be observed in the white sample, while a less intense peak of $\mathrm{CaCO}_{3}$ appears at $29.6^{\circ}$, which is consistent with previous reports $[17,18,42]$. This clearly indicates that the sample at the surface of the eggshell pile almost completely thermally decomposes to calcium oxide. The average crystallite particle sizes were calculated from the sharp XRD peak patterns using the Scherrer equation and were found to be $88.4 \pm 0.9 \mathrm{~nm}$ and $85.4 \pm 2.3 \mathrm{~nm}$ for the black and white samples calcined at $900^{\circ} \mathrm{C}$ for $3 \mathrm{~h}$, respectively. The average crystallite particle sizes for the black and the white samples calcined at $900^{\circ} \mathrm{C}$ for $4 \mathrm{~h}$ are $88.2 \pm 1.0 \mathrm{~nm}$ and $86.1 \pm 1.1 \mathrm{~nm}$, respectively. These results indicate that a long calcination time probably has a minor effect on the crystallite particle size. In comparison, the crystallite size of these black and white calcined eggshell samples is different from the crystallite size of natural eggshell $(93 \mathrm{~nm})$ [43]. In addition, chemically treated nano-calcium oxide derived from eggshell has a crystallite size of $46 \mathrm{~nm}$ and $82 \mathrm{~nm}$ [44]. Finally, pure chemical grade calcium oxide $(66.3 \mathrm{~nm})$ [45] and calcium oxide obtained from limestone calcined at $900^{\circ} \mathrm{C}$ for $30 \mathrm{~min}$ in a $\mathrm{N}_{2}$ atmosphere $(\sim 57 \mathrm{~nm})$ also has different crystallite sizes [46]. The different crystallite sizes of the calcium oxide materials most likely depend on several factors, such as the origin of the raw material, the pretreatment of raw materials, the rate of thermal decomposition, the calcination temperature, the calcination atmosphere, and the calcination time [47,48].

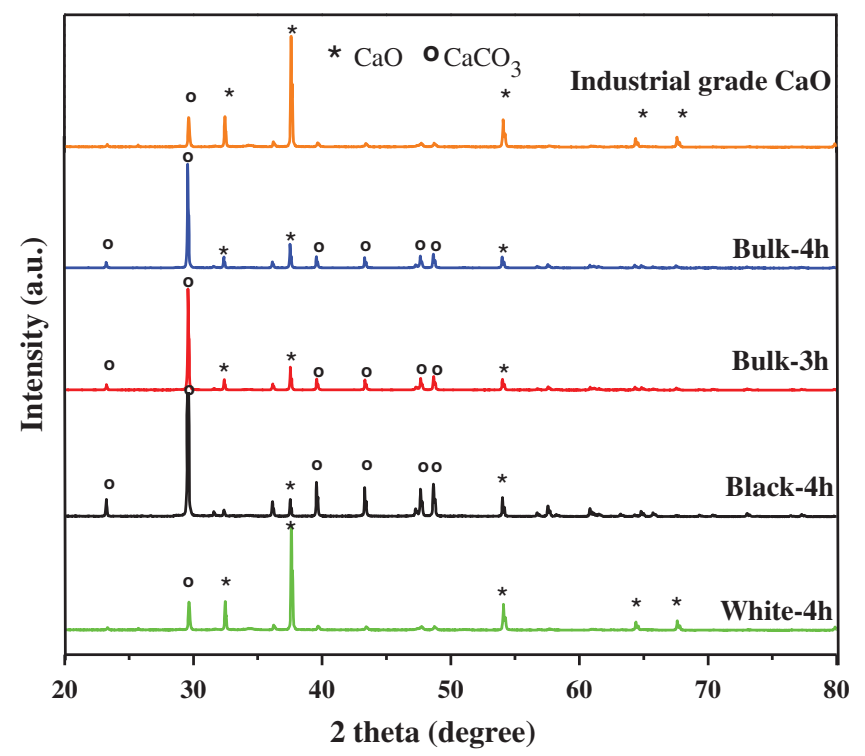

Figure 6: $\mathrm{XRD}$ patterns of the bulk calcined eggshells prepared at $900^{\circ} \mathrm{C}$ for $3 \mathrm{~h}$ (bulk-3h) and $4 \mathrm{~h}$ (bulk$4 \mathrm{~h}$ ), with the white and black calcined samples are separated from the bulk calcined eggshells prepared at $900^{\circ} \mathrm{C}$ for $4 \mathrm{~h}$ (denoted as black-4h and white-4h) 


\subsection{Fourier Transforms Infrared Spectroscopy}

Qualitative analysis based on characteristic frequencies provides useful information to identify chemical constituents in the calcined samples. In this study, the FT-IR data is similar to the SEM and XRD findings. The IR spectra for the calcined samples in the range of 500-4000 $\mathrm{cm}^{-1}$ are shown in Fig. 7. The bands at 1406,862 , and $710 \mathrm{~cm}^{-1}$ correspond to the asymmetric $\mathrm{C}=\mathrm{O}$ stretching, showing a bond between the oxygen atom of the carbonate and the calcium atom [49]. The extra stretching of $\mathrm{Ca}-\mathrm{O}$ at $\sim 407 \mathrm{~cm}^{-1}$ indicates the formation of calcium oxide. In addition, three very weak IR absorption bands of the bulk$3 \mathrm{~h}$, bulk-4h, and black calcined samples were found in the spectrum at $\sim 3620 \mathrm{~cm}^{-1}$, indicating the formation of basic $\mathrm{OH}$ groups, which are attached to the calcium atoms. It is worth noting that the white sample exhibits a weak transmittance only for the bands at 1474,872 , and $710 \mathrm{~cm}^{-1}$, whereas a broad frequency band is observed at $407 \mathrm{~cm}^{-1}$. This result indicates the formation of calcium oxide, as the carbonate in the eggshell decomposes. These results are comparable to previous published data $[12,17,50]$.

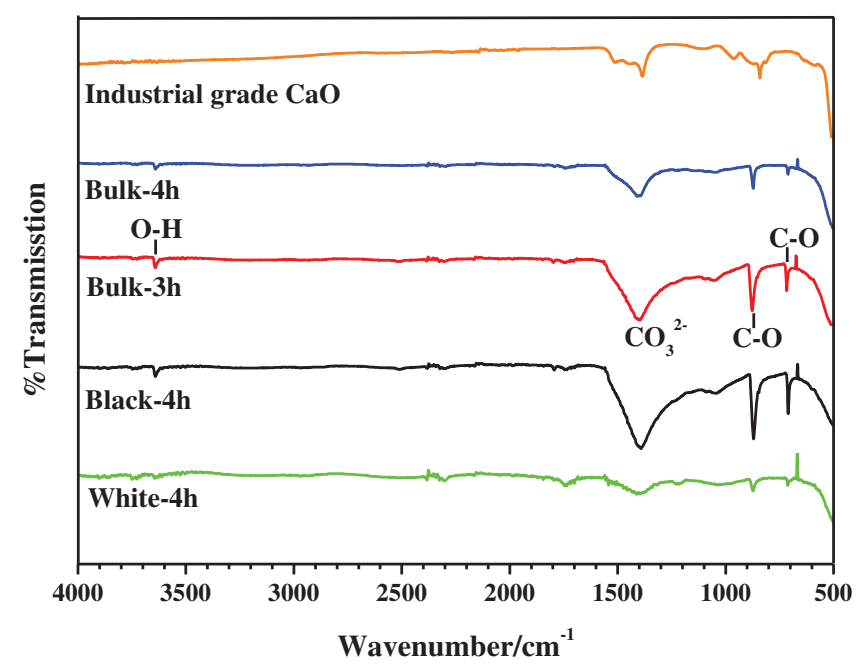

Figure 7: FT-IR spectra of the bulk calcined eggshells prepared at $900^{\circ} \mathrm{C}$ for $3 \mathrm{~h}$ (bulk-3h) and $4 \mathrm{~h}$ (bulk-4h), with the white and black calcined samples separated from the bulk calcined eggshells prepared at $900^{\circ} \mathrm{C}$ for $4 \mathrm{~h}$ (denoted as black-4h and white-4h)

\subsection{Chemical Composition of the Samples}

The chemical composition of the calcined eggshell materials determined by XRF on a dry basis and the loss on ignition values (LOI) are presented in Table 2. The bio-calcium oxide produced by calcination of the eggshell waste at $900^{\circ} \mathrm{C}$ for 3 and $4 \mathrm{~h}$ mainly consists of calcium oxide with contents $79.7 \mathrm{wt} \%$ and $87.4 \mathrm{wt} \%$, respectively. The residual mass is composed of different metal oxides, e.g., $\mathrm{MgO}, \mathrm{P}_{2} \mathrm{O}_{5}, \mathrm{SO}_{3}$, $\mathrm{SiO}_{2}, \mathrm{Na}_{2} \mathrm{O}, \mathrm{SrO}, \mathrm{K}_{2} \mathrm{O}, \mathrm{CuO}, \mathrm{Fe}_{2} \mathrm{O}_{3}$, and $\mathrm{Cl}$ in trace amounts. Meanwhile, the LOI values of the calcined eggshell samples prepared at $900^{\circ} \mathrm{C}$ for 3 and $4 \mathrm{~h}$ are 17.81 and 10.19 , respectively. The high LOI value of the bulk-3h sample indicates an extensive release of organic matter, which is still contained in the bulk-3h sample. It is clear that the amount of calcium oxide in the bio-quicklime increased by approximately $8.8 \%$ upon increasing the calcination time from $3 \mathrm{~h}$ to $4 \mathrm{~h}$. This might have been caused by the longer calcination time increasing the extent of decomposition of the calcium carbonate in the eggshell, with the formation of calcium oxide and the release of carbon dioxide. This greater extent of decomposition is in reasonable agreement with the lower LOI value of the bulk-4h sample, compared to the LOI value of the bulk-3h sample. Although the purity of the calcium oxide increases with increasing the calcination time, it possibly results in a lowering of the surface area of the calcium oxide product, 
thus resulting in a low reactivity or the generation of burned lime [23,51]. Moreover, longer calcination times signify lower amounts of product and higher costs for production.

Table 2: Major chemical components of raw materials (wt\%) as measured by XRF

\begin{tabular}{|c|c|c|c|c|c|c|c|c|c|}
\hline Compound & $\begin{array}{l}\text { Bulk- } \\
3 \mathrm{~h}\end{array}$ & $\begin{array}{l}\text { Bulk- } \\
4 \mathrm{~h}\end{array}$ & $\begin{array}{l}\text { Black } \\
\text { sample }\end{array}$ & $\begin{array}{l}\text { White } \\
\text { sample }\end{array}$ & $\begin{array}{l}\text { Raw } \\
\text { eggshell } \\
{[52]}\end{array}$ & $\begin{array}{l}\text { Calcined } \\
\text { eggshell } \\
{[52]}\end{array}$ & $\begin{array}{l}\text { Calcined } \\
\text { eggshell [53] }\end{array}$ & $\begin{array}{l}\text { TIS. } \\
319 \\
\text { Grade } \\
1^{*}\end{array}$ & $\begin{array}{l}\text { TIS. } \\
319 \\
\text { Grade } \\
2^{*}\end{array}$ \\
\hline $\mathrm{CaO}$ & 79.7 & 87.4 & 76.4 & 91.5 & 70.62 & 79.49 & 89.8 & $\geq 90$ & $\geq 88$ \\
\hline $\mathrm{MgO}$ & 0.88 & 1.16 & 0.89 & 0.98 & 1.09 & 1.09 & 0.01 & $\leq 1.8$ & $\leq 2$ \\
\hline $\mathrm{P}_{2} \mathrm{O}_{5}$ & 0.45 & 0.50 & 0.38 & 0.33 & 0.48 & 0.47 & 0.26 & - & - \\
\hline $\mathrm{SO}_{3}$ & 0.49 & 0.14 & 0.18 & 0.26 & 0.29 & 0.29 & 0.63 & $\leq 0.5$ & $\leq 1.0$ \\
\hline $\mathrm{SiO}_{2}$ & 0.05 & 0.06 & 0.14 & 0.05 & 0.33 & 0.41 & 0.10 & - & - \\
\hline $\mathrm{Na}_{2} \mathrm{O}$ & 0.17 & 0.26 & 0.08 & 0.12 & 0.15 & 0.16 & 0.21 & - & - \\
\hline $\mathrm{SrO}$ & 0.03 & 0.03 & 0.03 & 0.03 & - & - & - & - & - \\
\hline $\mathrm{K}_{2} \mathrm{O}$ & 0.17 & 0.14 & 0.02 & 0.04 & 0.05 & 0.05 & - & - & - \\
\hline $\mathrm{Fe}_{2} \mathrm{O}_{3}$ & 0.01 & 0.02 & 0.01 & 0.02 & 0.01 & 0.01 & 0.03 & $\leq 0.4$ & $\leq 0.4$ \\
\hline $\mathrm{CuO}$ & 0.007 & 0.007 & 0.005 & 0.006 & - & - & - & - & - \\
\hline $\mathrm{ZrO}_{2}$ & 0.0001 & 0.0011 & 0.0001 & - & - & - & - & - & - \\
\hline $\mathrm{Cl}$ & 0.14 & 0.06 & - & - & 0.02 & 0.02 & - & - & - \\
\hline $\mathrm{Al}_{2} \mathrm{O}_{3}$ & 0.05 & 0.01 & 0.17 & 0.06 & 0.41 & 0.06 & 0.32 & $\leq 1.0$ & $\leq 1.0$ \\
\hline $\begin{array}{l}\text { Loss on } \\
\text { ignition } \\
(\mathrm{LOI})\end{array}$ & 17.81 & 10.19 & 21.69 & 6.60 & 26.5 & 17.79 & 11.5 & & \\
\hline
\end{tabular}

Note: Remark * TIS. 319 Part 1 Thai industrial standards institute B.E. 2511.

It was also observed that the white and black samples separated from the calcined eggshell prepared at $900^{\circ} \mathrm{C}$ for $4 \mathrm{~h}$ had calcium oxide contents of $76.4 \mathrm{wt} \%$ and $91.5 \mathrm{wt} \%$, respectively. Furthermore, the LOI of the white calcined sample is much lower than that of the black calcined sample. In comparison, El-Kemary et al. [52] prepared eggshell waste obtained from a hypermarket by boiling, peeling, drying, and crushing into a powder, followed by calcination at $900^{\circ} \mathrm{C}$ in a laboratory furnace. They reported that the calcium oxide content in raw eggshells and calcined eggshells are $70.62 \mathrm{wt} \%$ and $79.49 \mathrm{wt} \%$, respectively. Eletta et al. [53] conducted a calcination experiment of the eggshell waste at $900^{\circ} \mathrm{C}$ for $4 \mathrm{~h}$ and reported that the calcium oxide content in the calcined product is approximately $89.8 \mathrm{wt} \%$. In conclusion, the purity of the bulk bio-calcium oxide produced by thermal decomposition of a large amount of eggshells in an industrial car bottom furnace is quite similar to the bio-limes produced by small-scale production in a laboratory furnace. However, the calcium oxide content in the white calcined sample is slightly higher than those calcined eggshell products heated in the laboratory furnace. This might be caused by different sample preparation methods and calcination conditions. In addition, the purity of the bulk bio-calcium oxide obtained from calcination carried out at $900^{\circ} \mathrm{C}$ for $4 \mathrm{~h}$ and the white calcined sample are comparable to the standards of industrial lime Grade 2 and Grade 1, respectively, set by the Thai industrial standards institute B.E. 2551. 


\section{Conclusions}

The study of the large-scale calcination of hatchery eggshell waste in an industrial-scale furnace was conducted. The effect of the calcination time was examined. The conversion of the hatchery eggshell waste from calcium carbonate to calcium oxide was analyzed by TGA, SEM, FTIR, XRD, and XRF methods. The results indicated that only the calcined eggshell material at the surface of the pile was completely converted to calcium oxide. The purity of the calcium oxide in the bulk bio-calcium oxide product varied from $79 \%$ to $87 \%$, but the purity of white sample separated from the surface of the calcined eggshell pile was approximately $91 \%$. This suggested that heat transfer efficiency in the furnace through the sample beneath the surface of the pile was likely limited. Thus, the production of high purity bio-calcium oxide by the calcination of a large pile of eggshell waste in the industrial car bottom furnace was most likely not effective. Additionally, increasing the calcination temperature and calcination time may not be possible for this study. This is due to the cost of LPG being approximately 80 baht (2.6 US\$) per $10 \mathrm{~kg}$ of bio-lime, which is approximately twice the cost of the industrial grade lime. On a final note, there are two suggestions for further experiments. Firstly, the oil burner system may be used instead of the LPG burner system in order to reduce the fuel cost. Secondly, the furnace with a mixing device or mechanism, e.g., a rotary kiln and a fluidized bed furnace, is preferable for providing a homogeneous and efficient heat transfer to the sample.

Funding Statement: Charoen Pokphand Foods Public Company Limited (CPF) and the Research and Researchers for Industry (RRI) project are highly appreciated for their financial support in this study. The authors are also grateful for receiving partial financial support from Mahasarakham University and thank the Laboratory Equipment Center, Mahasarakham University for their technical assistance.

Conflicts of Interest: The authors declare that they have no conflicts of interest to report regarding the present study.

\section{References}

1. Waheed, M., Yousaf, M., Shehzad, A., Inam-Ur-Raheem, M., Khan, M. K. I. et al. (2020). Channelling eggshell waste to valuable and utilizable products: A comprehensive review. Trends in Food Science \& Technology, 106, 78-90. DOI 10.1016/j.tifs.2020.10.009.

2. Glatz, P., Miao, Z., Rodda, B. (2011). Handling and treatment of poultry hatchery waste: A review. Sustainability, 3(1), 216-237. DOI 10.3390/su3010216.

3. Putkham, A. I., Ladhan, S., Putkham, A. (2018). Factors affecting the particle size of bio-calcium carbonate synthesized from industrial eggshell waste. Materials Transactions, 59(8), 1220-1224. DOI 10.2320/ matertrans.MF201708.

4. Hart, A. (2020). Mini-review of waste shell-derived materials' applications. Waste Management \& Research, 38(5), 514-527. DOI 10.1177/0734242X19897812.

5. Ketta, M., Tůmová, E. (2016). Eggshell structure, measurements, and quality-affecting factors in laying hens: A review. Czech Journal of Animal Science, 61(7), 299-309. DOI 10.17221/46/2015-CJAS.

6. Baláž, M., Boldyreva, E. V., Rybin, D., Pavlović, S., Rodríguez-Padrón, D. et al. (2021). State-of-the-Art of eggshell waste in materials science: Recent advances in catalysis, pharmaceutical applications, and mechanochemistry. Frontiers in Bioengineering and Biotechnology, 8(1522), 1-28. DOI 10.3389/fbioe.2020.612567.

7. Waheed, M., Butt, M. S., Shehzad, A., Adzahan, N. M., Shabbir, M. A. et al. (2019). Eggshell calcium: A cheap alternative to expensive supplements. Trends in Food Science \& Technology, 91(1), 219-230. DOI 10.1016/j. tifs.2019.07.021.

8. Aditya, S., Stephen, J., Radhakrishnan, M. (2021). Utilization of eggshell waste in calcium-fortified foods and other industrial applications: A review. Trends in Food Science \& Technology, 115(3), 422-432. DOI 10.1016/ j.tifs.2021.06.047. 
9. Ferraz, E., Gamelas, J. A. F., Coroado, J., Monteiro, C., Rocha, F. (2018). Eggshell waste to produce building lime: Calcium oxide reactivity, industrial, environmental and economic implications. Materials and Structures, 51(5), 128. DOI 10.1617/s11527-018-1243-7.

10. Mignardi, S., Archilletti, L., Medeghini, L., de Vito, C. (2020). Valorization of eggshell biowaste for sustainable environmental remediation. Scientific Reports, 10(1), 176. DOI 10.1038/s41598-020-59324-5.

11. Hashemi, S. M., Karami, D., Mahinpey, N. (2020). Solution combustion synthesis of zirconia-stabilized calcium oxide sorbents for $\mathrm{CO}_{2}$ capture. Fuel, 269, 117432. DOI 10.1016/j.fuel.2020.117432.

12. Nath, D., Jangid, K., Susaniya, A., Kumar, R., Vaish, R. (2021). Eggshell derived CaO-Portland cement antibacterial composites. Composites Part C: Open Access, 5, 100123. DOI 10.1016/j.jcomc.2021.100123.

13. Sari, Y. W., Listiani, E., Putri, S. Y., Abidin, Z. (2020). Prospective of eggshell nanocalcium in improving biogas production from palm oil mill effluent. Waste and Biomass Valorization, 11(9), 4631-4638. DOI 10.1007/ s12649-019-00786-8.

14. Horta, M. K. S., Moura, F. J., Aguilar, M. S., Westin, C. B., Campos, J. B. et al. (2020). Nanostructured hydroxyapatite from hen's eggshells using sucrose as a template. Materials Research, 23, 1-8. DOI 10.1590/ 1980-5373-MR-2020-0266.

15. Das Lala, S., Barua, E., Deb, P., Deoghare, A. B. (2021). Physico-chemical and biological behaviour of eggshell bio-waste derived nano-hydroxyapatite matured at different aging time. Materials Today Communications, 27, 102443. DOI 10.1016/j.mtcomm.2021.102443.

16. Minakshi, M., Higley, S., Baur, C., Mitchell, D. R. G., Jones, R. T. et al. (2019). Calcined chicken eggshell electrode for battery and supercapacitor applications. RSC Advances, 9(46), 26981-26995. DOI 10.1039/ C9RA04289J.

17. Tsuboi, Y., Koga, N. (2018). Thermal decomposition of biomineralized calcium carbonate: Correlation between the thermal behavior and structural characteristics of avian eggshell. ACS Sustainable Chemistry \& Engineering, 6(4), 5283-5295. DOI 10.1021/acssuschemeng.7b04943.

18. Engin, B., Demirtaş, H., Eken, M. (2006). Temperature effects on egg shells investigated by XRD, IR and ESR techniques. Radiation Physics and Chemistry, 75(2), 268-277. DOI 10.1016/j.radphyschem.2005.09.013.

19. Ayodeji, A. A., Modupe, O. E., Rasheed, B., Ayodele, J. M. (2018). Data on $\mathrm{CaO}$ and eggshell catalysts used for biodiesel production. Data in Brief, 19(2), 1466-1473. DOI 10.1016/j.dib.2018.06.028.

20. Cree, D., Rutter, A. (2015). Sustainable bio-inspired limestone eggshell powder for potential industrialized applications. ACS Sustainable Chemistry \& Engineering, 3(5), 941-949. DOI 10.1021/acssuschemeng.5b00035.

21. Vanthana Sree, G., Nagaraaj, P., Kalanidhi, K., Aswathy, C. A., Rajasekaran, P. (2020). Calcium oxide a sustainable photocatalyst derived from eggshell for efficient photo-degradation of organic pollutants. Journal of Cleaner Production, 270, 122294. DOI 10.1016/j.jclepro.2020.122294.

22. Pornchai, T., Putkham, A. I., Putkham, A. (2016). Effect of calcination time on physical and chemical properties of CaO-catalyst derived from industrial-eggshell wastes. Journal of Science and Technology Mahasarakham University, 35(6), 693-697.

23. Putkham, A., Ladhan, S., Putkham, A. I. (2020). Changing of particle size and pore structures of calcium oxide during calcinations of industrial eggshell waste. Materials Science Forum, 998, 90-95. DOI 10.4028/www. scientific.net/MSF.998.90.

24. Zhang, M., Li, J., Xue, Z., Zhu, R., Mou, Q. et al. (2021). Evolution of physicochemical properties of quick lime at converter-smelting temperature. High Temperature Materials and Processes, 40(1), 32-39. DOI 10.1515/htmp2021-0008.

25. Liu, H., Pan, F., Wu, S. (2019). The grain growth mechanism of nano-CaO regenerated by nano- $\mathrm{CaCO}_{3}$ in calcium looping. RSC Advances, 9(46), 26949-26955. DOI 10.1039/c9ra03611c.

26. Zhu, Y., Wu, S., Wang, X. (2011). Nano CaO grain characteristics and growth model under calcination. Chemical Engineering Journal, 175, 512-518. DOI 10.1016/j.cej.2011.09.084.

27. Niessen, W. R. (2010). Combustion and incineration processes: Applications in environmental engineering. Boca Raton: CRC Press. 
28. Pathare, P. B., Opara, U. L., Al-Said, F. A. J. (2013). Colour measurement and analysis in fresh and processed foods: A review. Food and Bioprocess Technology, 6(1), 36-60. DOI 10.1007/s11947-012-0867-9.

29. Rahman, M. M., Netravali, A. N., Tiimob, B. J., Rangari, V. K. (2014). Bioderived green composite from soy protein and eggshell nanopowder. ACS Sustainable Chemistry \& Engineering, 2(10), 2329-2337. DOI $10.1021 / \mathrm{sc} 5003193$.

30. Lubis, G., Hasyim, S. F. S., Arifin, K. S. (2021). Added value of limestone batumilmil and its application in industry. Journal of Physics: Conference Series, 1793(1), 012053. DOI 10.1088/1742-6596/1793/1/012053.

31. Li, X. G., Lv, Y., Ma, B. G., Wang, W. Q., Jian, S. W. (2017). Decomposition kinetic characteristics of calcium carbonate containing organic acids by TGA. Arabian Journal of Chemistry, 10, S2534-S2538. DOI 10.1016/j. arabjc.2013.09.026.

32. Fedunik-Hofman, L., Bayon, A., Donne, S. W. (2019). Comparative kinetic analysis of $\mathrm{CaCO}_{3} / \mathrm{CaO}$ reaction system for energy storage and carbon capture. Applied Sciences, 9(21), 4601. DOI 10.3390/app9214601.

33. Hincke, M. T., Nys, Y., Gautron, J., Mann, K., Rodriguez-Navarro, A. B. et al. (2012). The eggshell: Structure, composition and mineralization. Frontiers in Bioscience, 17, 1266-1280. DOI 10.2741/3985.

34. Bharadwaj, A. V. S. L. S., Singh, M., Niju, S., Begum, K. M. M. S., Anantharaman, N. (2019). Biodiesel production from rubber seed oil using calcium oxide derived from eggshell as catalyst-optimization and modeling studies. Green Processing and Synthesis, 8(1), 430-442. DOI 10.1515/gps-2019-0011.

35. Viriya-empikul, N., Krasae, P., Nualpaeng, W., Yoosuk, B., Faungnawakij, K. (2012). Biodiesel production over Ca-based solid catalysts derived from industrial wastes. Fuel, 92(1), 239-244. DOI 10.1016/j.fuel.2011.07.013.

36. da Silva Castro, L., Barañano, A. G., Pinheiro, C. J. G., Menini, L., Pinheiro, P. F. (2019). Biodiesel production from cotton oil using heterogeneous $\mathrm{CaO}$ catalysts from eggshells prepared at different calcination temperatures. Green Processing and Synthesis, 8(1), 235-244. DOI 10.1515/gps-2018-0076.

37. Trinks, W., Mawhinney, M. H., Shannon, R. A., Reed, R. J., Garvey, J. R. (2003). Heat transfer in industrial furnaces-Industrial Furnaces, pp. 25-69. New Jersey: John Wiley \& Sons, Inc.

38. Niessen, W. R. (2010). Combustion and incineration processes: Applications in environmental engineering. Boca Raton: CRC Press.

39. Okwundu, O. S., El-Shazly, A. H., Elkady, M. (2019). Comparative effect of reaction time on biodiesel production from low free fatty acid beef tallow: A definition of product yield. SN Applied Sciences, 1(2), 140. DOI 10.1007/ s42452-018-0145-1.

40. Hassan, T. A., Rangari, V. K., Jeelani, S. (2014). Value-added biopolymer nanocomposites from waste eggshellbased $\mathrm{CaCO}_{3}$ nanoparticles as fillers. ACS Sustainable Chemistry \& Engineering, 2(4), 706-717. DOI 10.1021/ sc400405v.

41. Trisupakitti, S., Ketwong, C., Senajuk, W., Phukapak, C., Wiriyaumpaiwong, S. (2018). Golden apple cherry snail as catalyst for heterogeneous transesterification of biodiesel. Brazilian Journal of Chemical Engineering, 35, 1283-1291. DOI 10.1590/0104-6632.20180354s20170537.

42. Wong, Y. C., Ang, R. X. (2018). Study of calcined eggshell as potential catalyst for biodiesel formation using used cooking oil. Open Chemistry, 16(1), 1166-1175. DOI 10.1515/chem-2018-0127.

43. Nagabhushana, K. R., Lokesha, H. S., Satyanarayana Reddy, S., Prakash, D., Veerabhadraswamy, M. et al. (2017). Thermoluminescence properties of $\mathrm{CaO}$ powder obtained from chicken eggshells. Radiation Physics and Chemistry, 138, 54-59. DOI 10.1016/j.radphyschem.2017.03.015.

44. Madhu, B. J., Bhagyalakshmi, H., Shruthi, B., Veerabhadraswamy, M. (2021). Structural, AC conductivity, dielectric and catalytic behavior of calcium oxide nanoparticles derived from waste eggshells. SN Applied Sciences, 3(6), 637. DOI 10.1007/s42452-021-04607-3.

45. Teo, S. H., Taufiq-Yap, Y. H., Rashid, U., Islam, A. (2015). Hydrothermal effect on synthesis, characterization and catalytic properties of calcium methoxide for biodiesel production from crude Jatropha curcas. RSC Advances, 5(6), 4266-4276. DOI 10.1039/c4ra11936c.

46. Rodriguez-Navarro, C., Ruiz-Agudo, E., Luque, A., Rodriguez-Navarro, A. B., Ortega-Huertas, M. (2009). Thermal decomposition of calcite: Mechanisms of formation and textural evolution of $\mathrm{CaO}$ nanocrystals. American Mineralogist, 94(4), 578-593. DOI 10.2138/am.2009.3021. 
JRM, 2022, vol.10, no.4

47. Valverde, J. M., Medina, S. (2015). Crystallographic transformation of limestone during calcination under $\mathrm{CO}_{2}$. Physical Chemistry Chemical Physics, 17(34), 21912-21926. DOI 10.1039/c5cp02715b.

48. Biasin, A., Segre, C. U., Salviulo, G., Zorzi, F., Strumendo, M. (2015). Investigation of CaO-CO $\mathrm{CO}_{2}$ reaction kinetics by in-situ XRD using synchrotron radiation. Chemical Engineering Science, 127, 13-24. DOI 10.1016/j. ces.2014.12.058.

49. Loy, C. W., Amin Matori, K., Lim, W. F., Schmid, S., Zainuddin, N. et al. (2016). Effects of calcination on the crystallography and nonbiogenic aragonite formation of ark clam shell under ambient condition. Advances in Materials Science and Engineering, 2016, 2914368. DOI 10.1155/2016/2914368.

50. Ye, M., Sun, M., Chen, X., Feng, Y., Wan, J. et al. (2017). Feasibility of sulfate-calcined eggshells for removing pathogenic bacteria and antibiotic resistance genes from landfill leachates. Waste Management, 63, 275-283. DOI 10.1016/j.wasman.2017.03.005.

51. Piringer, H. (2017). Lime Shaft Kilns. Energy Procedia, 120, 75-95. DOI 10.1016/j.egypro.2017.07.156.

52. El-Kemary, M. A., El-mehasseb, I. M., Shoueir, K. R., El-Shafey, S. E., El-Shafey, O. I. et al. (2018). Sol-gel TiO decorated on eggshell nanocrystal as engineered adsorbents for removal of acid dye. Journal of Dispersion Science and Technology, 39(6), 911-921. DOI 10.1080/01932691.2017.1410829.

53. Eletta, O. A. A., Ajayi, O. A., Ogunleye, O. O., Akpan, I. C. (2016). Adsorption of cyanide from aqueous solution using calcinated eggshells: Equilibrium and optimisation studies. Journal of Environmental Chemical Engineering, 4(1), 1367-1375. DOI 10.1016/j.jece.2016.01.020. 